\title{
KESIAPAN FUNGSI JALAN PERINTINS KEMERDEKAAN, PANDANARAN, NANGKA GUMULAN SETELAH ADANYA KANTOR PEMERINTAHAN TERPADU KABUPATEN BOYOLALI
}

\author{
Citra Ayu Permatasari', Soedwiwahjono', Kuswanto Nurhadi2 \\ 1Program Studi Perencanaan Wilayah dan Kota Fakultas Teknik Universitas Negeri Sebelas Maret \\ 2Program Studi Teknik Sipil Fakultas Teknik Universitas Negeri Sebelas Maret
}

\begin{abstract}
Abstrak
Transportasi merupakan kebutuhan dasar manusia dalam melakukan aksesibilitas dan mobilitas. Untuk memenuhi kebutuhan manusia tersebut, dibutuhkan jalan sebagai fungsi utama dari sistem transportasi. Fenomena transportasi di Kabupaten Boyolali adalah Pemindahan Kantor Pemerintahan Terpadu Kabupaten Boyolali yang terletak di antara ruas Jalan Perintis Kemerdekaan, Jalan Pandanaran dan Jalan Nangka Gumulan. Isu pemindahan Kantor Pemerintahan nantinya akan berdampak pada meningkatnya arus lalu lintas. Oleh karena itu kesiapan fungsi jalan dapat diukur dari sistem jaringan jalan yang digunakan dalam melayani kebutuhan di kantor pemerintahan terpadu Kabupaten Boyolali. Tujuan dalam penelitian ini adalah untuk mengetahui kesiapan ruas Jalan Perintis Kemerdekaan, Pandanaran dan Nangka Gumulan setelah adanya Kantor Pemerintahan terpadu Kabupaten Boyolali dengan beberapa variabel penelitian diantaranya, (1) ketuntasan dalam pengembangan jaringan jalan, (2) tingkat pelayanan jalan, (3) ketersediaan moda transportasi, (4) ketersediaan lahan parkir, (5) fungsi sarana dan prasarana jalan, (6) tingkat fungsi lembaga. Penelitian ini merupakan penelitian kuantitatif dengan menggunakan teknik analisis deskriptif kuantitatif dan analisis skoring. Analisis skoring dilakukan pada masing-masing variabel penelitian. Hasil akhir yang diperoleh, bahwa ke tiga ruas jalan siap mendukung keberadaan Kantor Pemerintahan Terpadu Kabupaten Boyolali. Namun terdapat beberapa variabel penelitian yang masih memerlukan peningkatkan guna pengoptimalan fungsi jalan pada masing-masing ruas jalan. Salah satunya adanya rekayasa lalu lintas untuk mengoptimalkan fungsi jalan pada ruas Jalan Kantor Pemerintahan Terpadu Kabupaten Boyolali.
\end{abstract}

Kata kunci : kesiapan; sistem jaringan jalan; sistem kegiatan

Abstract

Transportation is one of human's basic need on doing mobility and access different places. To fulfill those needs, roads were made to fulfill the main function of transportation. The transportation phenomena in Kabupaten Boyolali is relocation of the Integrated Government' offices of Kabupaten Boyolali onto an area located between Perintis Kemerdekaan, Pandanaran, and Nangka Gumulan street. The issue of this relocation were going to had some impacts, like the increase of traffic. Determining the readiness of road functions could be measured by the road network system used to support the needs on the Integrated Government' offices of Kabupaten Boyolali. The aim of this research is to determine the readiness of Perintis Kemerdekaan, Pandanaran, and Nangka Gumulan's street section after the relocation of the Integrated Government' offices of Kabupaten Boyolali with some research variables, which are (1) completeness of street network development, (2) level of road service, (3) availability of public transportation modes, (4) availability of parking space,(5) function of street infrastructure, (6) level of government functions. This research is a qualitative research which used quantitative descriptive analysis and scoring analysis. Scoring Analysis were used on each variables of the research. The obtained result are all three streets were ready to support the relocation and the activities of the Integrated Government' offices of Kabupaten Boyolali. But there were some research variables whom needs more improvement to optimalize the road functions at each of the streets. One of the improvement are traffic engineering to further optimalize the road function at the streets of Kabupaten Boyolali's Integrated Government offices.

Keywords : activity system; readines; street network system

\section{PENDAHULUAN}

Jalan memiliki peranan penting dalam transportasi, karena menjadi penghubung antara suatu pusat kegiatan maupun antar suatu wilayah (Munawar, 2004). Dijelaskan pada sistem transportasi makro, terdapat sistem jaringan dan sistem kegiatan yang keduanya saling berhubungan dan menyebabkan adanya sistem pergerakan (Tamin, 1997). Sistem jaringan akan mempengaruhi sistem kegiatan yang menghasilkan suatu pergerakan atau mobilitas, sedangkan 
sistem kegiatan merupakan rencana tata guna lahan seperti kegiatan perdagangan, pendidikan serta perkantoran. Sistem kegiatan yang berupa perkantoran, identik dengan kawasan pemerintahan maupun swasta, dimana kegiatan tersebut dapat menimbulkan suatu pergerakan bagi suatu kawasan.

Komplek Perkantoran Terpadu Kabupaten Boyolali diresmikan tahun 2013 tepatnya pada bulan Agustus, berada di Desa Kemiri Kecamatan Mojosongo. Disebutkan dalam Draft RDTR Kecamatan Mojosongo Tahun 2012-2032 bahwa adanya isu pemindahan kantor pemerintahan nantinya akan berdampak pada meningkatnya arus lalu lintas. Lokasi kantor pemerintahan terpadu juga merupakan jalur strategis yang menghubungkan Solo-Semarang sehingga memiliki potensi pengembangan kegiatan sosial ekonomi. Dari pemindahan kantor pemerintahan terpadu tersebut, terdapat fenomena transportasi perkotaan Boyolali yaitu infrastruktur dan lalu lintas khususnya di perkotaan Kabupaten Boyolali.

Aktivitas pemerintahan yang dipindahkan menuju Desa Kemiri, Kecamatan Mojosongo secara tidak langsung juga memindahkan aktivitas atau pergerakan masyarakat yang kemudian terdapat fenomena tingginya mobilitas peduduk dan menjadikan adanya perbedaan fungsi pada jalan. Berdasarkan Peta Rencana Struktur Ruang RTRW Kabupaten Boyolali Tahun 2011-2031 bahwa Jalan Pandanaran merupakan jalan arteri yang berfungsi sebagai pelayanan antar kota. Setelah adanya pemindahan kantor pemerintahan terpadu, fungsi jalan yang awalnya hanya arteri, sekarang mempunyai fungsi lokal karena melayani masyarakat sekitar untuk melakukan mobilitas di kantor pemerintahan terpadu. Untuk Jalan Perintis Kemerdekaan dan Jalan Nangka Gumulan mempunyai fungsi jalan kolektor dengan fungsi melayani kegiatan wilayah dan lokal. Melihat adanya pusat kota baru di Kabupaten Boyolali serta melihat kesiapan fungsi jalan yang seharusnya dilakukan oleh Pemerintah Kabupaten Boyolali, perlunya melihat kondisi kawasan sekitar Pemerintahan Terpadu Kabupaten Boyolali dari beberapa aspek, terutama masalah infrastruktur jalan. Kesiapan dapat diartikan bahwa suatu rencana untuk direalisasikan seharusnya memperhatikan ketuntasan dalam rencana, kecukupan serta ketersediaan dukungan pelayanan dan sistem.

Maka dari itu, peneliti mengkaji tentang kesiapan fungsi Jalan Perintis Kemerdekaan, Pandanaran, Nangka Gumulan setelah adanya Kantor Pemerintahan Terpadu Kabupaten Boyolali untuk mengetahui tingkat kesiapan fungsi jalan pada masing-masing ruas jalan.

\section{KAJIAN TEORI}

\subsection{Kesiapan}

Menurut Kamus Besar Bahasa Indonesia (KBBI), pengertian kesiapan berasal dari kata "siap" yang berarti "sudah sedia", dimana kesiapan merupakan kondisi dari orang, sistem atau komunitas/organisasi untuk siap dalam menghadapi situasi serta melakukan tindakan yang terencana. Kesiapan merupakan kondisi untuk menyiapkan orang, sistem atau organisasi untuk menciptakan kondisi tertentu serta melakukan implementasi dari rangkaian rencana. Kesiapan didasarkan pada ketelitian rencana, kecukupan dan pelatihan dari pelaku serta ketersediaan dukungan pelayanan atau sistem (Business Dictionary, 2016).

Menurut Cities Readiess Invitation atau CRI menjelaskan tingkat kesiapan dapat dilihat dari dua aspek yaitu kapasitas dan kapabilitas. Kapabilitas terkait dengan sumber daya yang digunakan serta kapabilitas terkait dengan kemampuan operasional atau ketersediaan lembaga dan perannya dalam kegiatan (Nelson, 2009).

Dalam penelitian, kesiapan dijabarkan menjadi dua pokok bahasan yaitu kesiapan dari segi fisik perencanaan dan dari segi kemampuan operasional manajemen. Oleh karena itu, kesiapan dari segi fisik dilihat dari ketuntasan dalam rencana, kapasitas serta ketersediaan dukungan pelayanan dan sistem, sedangkan kemampuan operasional dilihat dari kapabilitas atau kemampuan lembaga dalam mengakomodir seluruh rencana yang ada.

\subsection{Sistem Jaringan Jalan}

Sistem adalah gabungan beberapa komponen atau objek yang saling berkaitan. Dalam setiap organisasi sistem, perubahan pada satu komponen dapat menyebabkan perubahan pada komponen lainnya (Tamin, 1997). Jaringan merupakan simpul-simpul yang berupa persimpangan/terminal yang dihubungkan dengan ruas-ruas jalan/trayek.

Sistem jaringan jalan merupakan suatu konsep matematis yang dapat memberikan informasi secara kuantitatif mengenai hubungan antara sistem transportasi dengan sistem lainnya (Morlok dalam Mujihartono, 1996). Dalam Undang-Undang Nomor 38 Tahun 2004 menguraikan sistem jaringan jalan adalah satu kesatuan ruas jalan yang saling 
menghubungkan dan mengikat pusat-pusat pertumbuhan dengan wilayah yang berada dalam pengaruh pelayanannya dalam satu hubungan hierarki. Sistem jaringan jalan merupakan abstraksi dari fasilitas transportasi yang memiliki kedudukan penting, terutama apabila dihubungkan dengan penggunaan lahan akan dapat membentuk suatu pola tata guna lahan yang dapat mempengaruhi rencana fisik ruang kota serta peranannya sebagai suatu sistem transportasi yaitu untuk menampung pergerakan manusia dan kendaraan (Creighton dalam Mujihartono, 1996).

Menurut UU No 38 Tahun 2004, jalan merupakan prasarana transportasi darat yang meliputi seluruh bagian jalan, yang didalamnya terdapat bangunan pelengkap yang diperlukan bagi lalu lintas. Sesuai peruntukannya, jalan menurut UU No 38 tahun 2004 terdiri dari jalan umum dan jalan khusus, dimana jalan umum dikelompokkan menurut sistemnya terdiri dari fungsi jalan, status dan kelas jalan.

Fungsi jalan menurut UU Nomor 38 Tahun 2004, dibedakan menjadi jalan arteri, jalan kolektor, jalan lokal dan jalan lingkungan:

1) Jalan arteri, merupakan jalan umum yang melayani angkutan utama dalam jarak jauh, kecepatan rata-rata tinggi serta jalan masuk dibatasi

2) Jalan kolektor, merupakan jalan umum yang berfungsi melayani angkutan pengumpul dengan ciri perjalanan jarak sedang, kecepatan rata-rata sedang dan jalan masuk dibatasi

3) Jalan lokal, merupakan jalan umum yang mempunyai fungsi dalam pelayanan angkutan setempat yang mempunyai ciri-ciri perjalanan jarak dekat, kecepatan rata-rata rendah dan jumlah jalan masuk tidak dibatasi.

4) Jalan lingkungan, merupakan jalan umum yang mempunyai fungsi pelayanan angkutan lingkungan dengan ciriciri perjalanan jarak dekat dan kecepatan rata-rata rendah

Berikut merupakan karakteristik sistem jaringan jalan yang dalam fokus penelitian terdiri dari dua fungsi jalan yaitu fungsi jalan arteri dan kolektor, antara lain:

1) Penghubung antar pusat kegiatan

Dalam fungsi jalan, memiliki sistem kegiatan yang saling dihubungkan. Untuk fungsi jalan arteri dan kolektor memiliki fungsi sebagai penghubung kegiatan nasional dengan wilayah dan nasional dengan lokal.

2) Dilewati oleh kendaraan berat dan bus

Kendaraan atau bus yang melewati fungsi jalan arteri dan kolektor merupakan kendaraan berat dan bus yang melayani kebutuhan kota. Untuk kendaraan berat diperbolehkan memakai jalan kolektor namun tidak di kawasan permukiman.

3) Tidak terganggu oleh aktivitas lokal

Aktivitas lokal merupakan aktivitas yang berada di dalam kawasan perkotaan, untuk fungsi jalan arteri tidak diperbolehkan terganggu oleh aktivitas lokal atau ulang alik karena jalan arteri merupakan fungsi jalan dengan lalu lintas jarak jauh dan kecepatan rata-rata tinggi.

4) Pembatas jalan untuk fungsi arteri

Untuk membedakan fungsi jalan arteri dengan jalan kolektor pada suatu kawasan diperlukan pembatas jalan atau sparator yang digunakan untuk membatasi pengguna yang masuk dalam suatu kawasan, dan untuk mengatur lalu lintas pada jalan arteri sehingga fungsi jalan tidak terganggu.

5) Pembatasan fungsi parkir di bahu jalan

Dalam fungsi jalan arteri dan kolektor diperlukan pembatasan fungsi lahan untuk parkir terutama pada bahu jalan karena tingkat kecepatan rata pada jalan arteri dan kolektor adalah tinggi dan sedang serta jalan arteri dan kolektor merupakan fungsi jalan untuk perjalanan jarak jauh dan sedang.

\subsection{Sistem Kegiatan}

Menurut Tamin, (1997) setiap tata guna lahan atau sistem kegiatan mempunyai jenis kegiatan yang nantinya akan membangkitkan pergerakan dan akan mampu menarik pergerakan dalam proses pemenuhan kebutuhan. Pergerakan dalam sistem kegiatan akan mempengaruhi sistem jaringan melalui perubahan pada tingkat pelayanan sistem pergerakan. Bangkitan pergerakan merupakan perkiraan pergerakan yang berasal dari suatu titik lokasi atau tata guna lahan dan jumlah yang tertarik ke suatu tata guna lahan atau titik lokasi lainnya. Dalam hal ini, pergerakan merupakan fungsi dari tata guna lahan yang menghasilkan pergerakan lalu lintas, baik yang meninggalkan lokasi atau menuju lokasi sering disebut dengan bangkitan. Sistem kegiatan merupakan bagian dari pergerakan suatu sistem transportasi yang dapat menghasilkan bangkitan, tarikan pergerakan. 
Dalam membangkitkan pergerakan yaitu bangkitan dan tarikan tergantung pada aspek tata guna lahan yaitu:

- Jenis tata guna lahan Jenis tata guna lahan terdiri dari jenis permukiman, pendidikan, pemerintahan, perdagangan yang masingmasing kegiatan mempunyai ciri-ciri bangkitan lalu lintas yang berbeda, di antaranya jumlah arus lalu lintas, jenis lalu lintas, dan lalu lintas pada waktu tertentu

- Jumlah aktivitas dan intensitas pengunaan lahan

Penggunaan lahan dalam satu lokasi yang padat akan menghasilkan pergerakan arus lalu lintas yang tinggi. Dalam hal ini bangkitan dan tarikan tidak hanya dipengaruhi oleh jenis tata guna lahan saja namun juga aktivitas yang ada di dalamnya seperti aktivitas perkantoran, permukiman, atau perdagangan. Untuk mengukur tingkat intensitas penggunaan lahan dalam sebidang tanah dilihat dari "kepadatannya". Semakin tinggi tingkat aktivitas suatu tata guna lahan maka akan semakin tinggi kemampuan dalam menarik lalu lintas didalamnya.

Setiap bangkitan dan tarikan dalam sistem kegiatan, mempunyai pergerakan lalu lintas yang berbeda, tergantung dari sistem kegiatan yang ada dalam satu kawasan. Dijelaskan oleh Raonels dalam Yunus, (1999) bahwa sistem-sistem kegiatan tersebut dapat digolongkan menjadi 3 yaitu sistem kegiatan rutin, terlembaga dan organinsasi.

Berikut merupakan karakteristik untuk sistem kegiatan dalam penelitian antara lain bangkitan dan tarikan, intensitas penggunaan lahan dan guna lahan.

\subsection{Fungsi Jalan Sebagai Hubungan Sistem Jaringan}

Hubungan karakteristik antara sistem jaringan dengan sistem kegiatan merupakan hasil dari sintesa teori yang telah dilakukan tinjauan oleh peneliti. Berdasarkan karakteristik sistem jaringan jalan dan sistem kegiatan yang telah dioperasionalkan, maka dapat dijelaskan hubungan keduanya sebagai berikut:

Tabel 1. Fungsi Jalan Sebagai Hasil Hubungan Sistem Jaringan Jalan dan Sistem Kegiatan

\begin{tabular}{|c|c|c|c|}
\hline \multirow[b]{2}{*}{ Sistem Jaringan Jalan } & \multicolumn{3}{|c|}{ Sistem Kegiatan } \\
\hline & Bangkitan dan Tarikan & $\begin{array}{c}\text { Intensitas } \\
\text { Penggunaan Lahan }\end{array}$ & Guna Lahan \\
\hline Penghubung antar pusat kegiatan & $\begin{array}{l}\text { Bangkitan dan tarikan } \\
\text { antar pusat kegiatan }\end{array}$ & - & - \\
\hline Dilewati oleh kendaraan berat dan bus & Moda Transportasi & - & - \\
\hline Tidak terganggu oleh aktivitas lokal & - & \multirow{2}{*}{$\begin{array}{l}\text { Pembatasan fungsi } \\
\text { jalan }\end{array}$} & - \\
\hline Pembatas jalan untuk fungsi arteri & - & & - \\
\hline Pembatasan fungsi parkir di bahu jalan & - & - & $\begin{array}{c}\text { Guna lahan parkir } \\
\text { dalam sistem kegiatan }\end{array}$ \\
\hline
\end{tabular}

Sumber : Permatasari, Citra Ayu, dkk., 2017

Berikut merupakan penjabaran dari fungsi sebagai hubungan sistem jaringan jalan dan sistem kegiatan:

1) Bangkitan dan tarikan antar pusat kegiatan

Sistem kegiatan menghasilkan suatu pergerakan yang disebut dengan bangkitan dan tarikan yang terjadi dalam suatu kawasan. Bangkitan dan tarikan menunjukkan adanya suatu sistem kegiatan tertentu pada suatu kawasan

2) Moda transportasi

Moda transportasi berhubungan dengan adanya sistem aktivitas di suatu kawasan yang menyebabkan bangkitan dan tarikan kawasan. Bangkitan dan tarikan dalam suatu kawasan dapat diketahui dari jumlah dan moda transportasi yang melewati pada sistem aktivitas tertentu.

3) Guna lahan parkir dalam sistem kegiatan

Apabila pembatasan parkir dihubungan dengan guna lahan, serta jalan digunakan sebagai lahan parkir, maka dalam suatu kawasan membutuhkan lahan parkir guna mendukung sistem aktivitas dan sistem jaringan agar pergerakan di kawasan tidak terganggu. 
4) Pembatasan fungsi jalan

Sparator atau pembatas jalan dibutuhkan dalam membedakan fungsi jalan arteri maupun kolektor dalam suatu wilayah. Jadi, pembatasan fungsi jalan dalam sistem jaringan dapat yang dimaksud adalah pembuatan sparator/pembatas jalan yang nantinya sistem pergerakan menuju ke sistem aktivitas tidak terganggu oleh sistem jaringan jalan.

\section{METODE PENELITIAN}

Jenis penelitian yang digunakan adalah penelitian kuantitatif dengan pendekatan secara deduktif. Dalam penelitian ini, dilakukan analisis skoring dari masing-masing indikator yang telah ditentukan. Adapun data yang diperoleh berdasarkan survey primer berupa observasi dan wawancara serta survey sekunder berupa studi dokumen yang diperoleh melalui instansi Dinas Perhubungan Kabupaten Boyolali, Dinas Bina Marga Jawa Tengah, Satuan Kerja Perencanaan dan Pengawasan Jalan Nasional Provinsi Jawa Tengah, Bappeda Kabupaten Boyolali. Data-data tersebut berupa tabel, peta, gambar/foto, deskripsi yang dapat digunakan dalam mendukung kebutuhan data penelitian. Teknik sampling untuk menentukan jumlah responden dalam penelitian, menggunakan teknik sampling populasi tak terhingga karena jumlah pengguna jalan pada ketiga ruas jalan tidak diketahui. Responden yang dipilih yaitu pengguna jalan dengan menggunakan teknik random sampling pada ketiga ruas jalan.

Berikut merupakan gambaran ruang lingkup penelitian yang terdiri dari 3 ruas jalan yaitu Jalan Pandanaran, Jalan Perintis Kemerdekaan dan Jalan Nangka Gumulan:

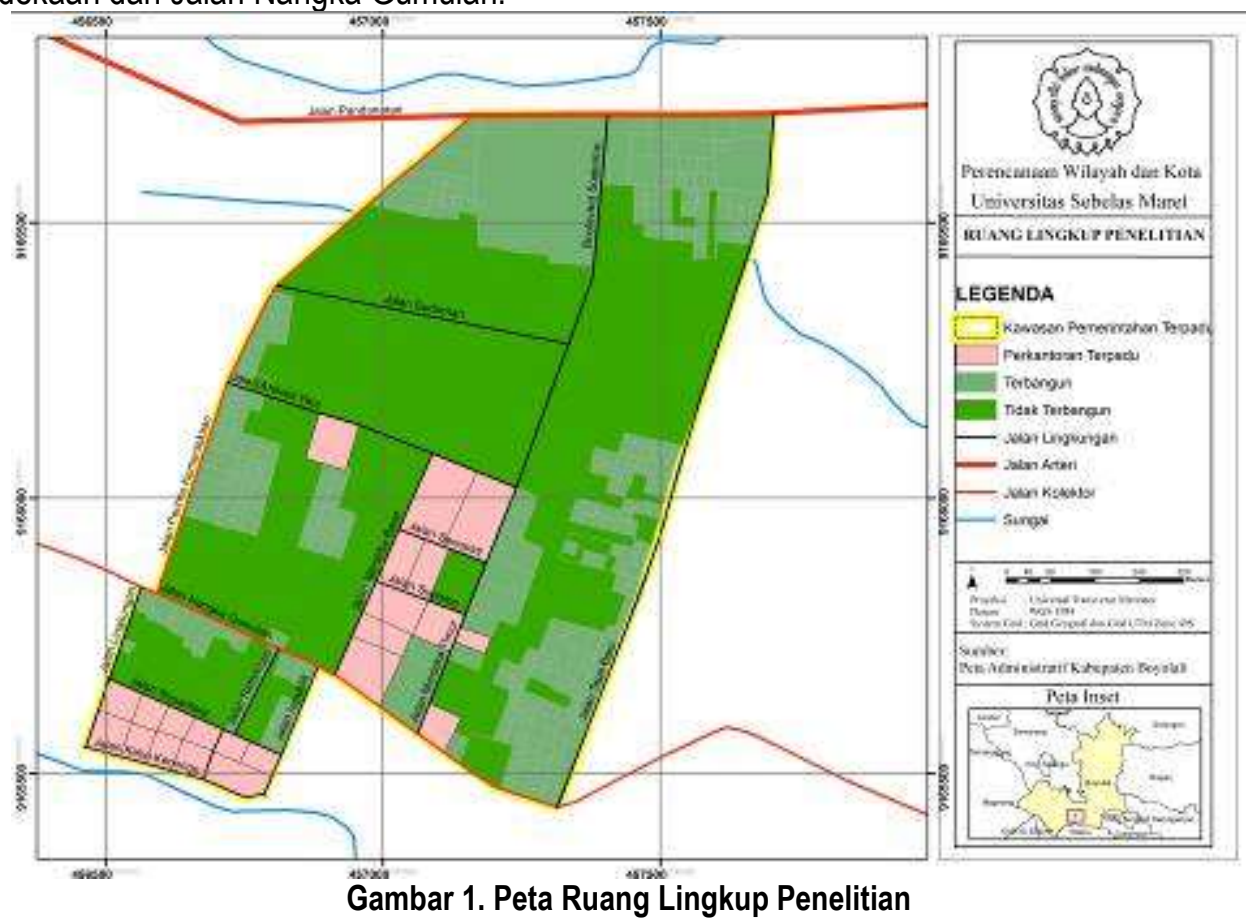

Dalam penelitian, digunakan beberapa variabel penelitian diantaranya:

Tabel 2. Variabel Penelitian

\begin{tabular}{|l|l|l|l|l|}
\hline \multicolumn{1}{|c|}{ VARIABEL } & \multicolumn{1}{|c|}{$\begin{array}{c}\text { SUB } \\
\text { VARIABEL }\end{array}$} & DEFINISI OPERASIONAL & \multicolumn{1}{c|}{ INDIKATOR } & \multicolumn{1}{c|}{ KETERANGAN } \\
\hline $\begin{array}{l}\text { Ketuntasan } \\
\text { dalam }\end{array}$ & $\begin{array}{l}\text { Menyebabkan } \\
\text { pengembangan } \\
\text { jaringan jalan } \\
\text { tarikan antar } \\
\text { pusat } \\
\text { kegiatan }\end{array}$ & $\begin{array}{l}\text { Menghitung jumlah } \\
\text { pergerakan lalu lintas yang } \\
\text { masuk dan keluar pada } \\
\text { satu kawasan per satuan } \\
\text { waktu }\end{array}$ & Tuntas dalam rencana & $\begin{array}{l}\text { Bernilai 2 apabila } \\
\text { menghasilkan lebih dari } \\
1000 \text { bangkitan } \\
\text { perjalanan/jam }\end{array}$ \\
\cline { 3 - 5 } & & Tidak tuntas dalam rencana & $\begin{array}{l}\text { Bernilai 1 apabila } \\
\text { menghasilkan lebih dari } \\
1000 \text { bangkitan } \\
\text { perjalanan/jam }\end{array}$ \\
\hline $\begin{array}{l}\text { Tingkat } \\
\text { Pelayanan }\end{array}$ & $\begin{array}{l}\text { Kemudahan } \\
\text { aksesibilitas }\end{array}$ & $\begin{array}{l}\text { Mengetahui tingkat } \\
\text { pelayanan jalan pada }\end{array}$ & $\begin{array}{l}\text { Tingkat pelayanan jalan } \\
\text { tinggi siap mendukung }\end{array}$ & $\begin{array}{l}\text { Nilai tingkat pelayanan } \\
\text { jalan 10,5 } \leq \text { nilai } \leq 18\end{array}$ \\
\hline
\end{tabular}




\begin{tabular}{|c|c|c|c|c|}
\hline VARIABEL & $\begin{array}{c}\text { SUB } \\
\text { VARIABEL }\end{array}$ & DEFINISI OPERASIONAL & INDIKATOR & KETERANGAN \\
\hline \multirow[t]{2}{*}{ Jalan } & & \multirow{2}{*}{$\begin{array}{l}\text { masing-masing ruas jalan } \\
\text { karena tingginya tingkat } \\
\text { pelayanan jalan } \\
\text { mempengaruhi tingkat } \\
\text { aksesibilitas }\end{array}$} & pusat aktivitas & \\
\hline & & & $\begin{array}{l}\text { Tingkat pelayanan jalan } \\
\text { rendah tidak siap } \\
\text { mendukung pusat aktivitas }\end{array}$ & $\begin{array}{l}\text { Nilai tingkat pelayanan } \\
\text { jalan } 3 \leq \text { nilai }<10,5\end{array}$ \\
\hline \multirow{2}{*}{$\begin{array}{l}\text { Ketersediaan } \\
\text { Moda } \\
\text { Transportasi }\end{array}$} & \multirow[t]{2}{*}{$\begin{array}{l}\text { Jenis Moda } \\
\text { Transportasi }\end{array}$} & \multirow{2}{*}{$\begin{array}{l}\text { Mengetahui moda } \\
\text { transportasi yang melewati } \\
\text { ruang jalan, untuk di } \\
\text { bandingkan dengan aturan } \\
\text { fungsi jalan }\end{array}$} & $\begin{array}{l}\text { Siap mendukung pusat } \\
\text { aktivitas }\end{array}$ & $\begin{array}{l}\text { Nilai dilewati moda } \\
\text { transportasi } 9 \leq \text { nilai } \leq 12\end{array}$ \\
\hline & & & $\begin{array}{l}\text { Tidak siap mendukung } \\
\text { pusat aktivitas }\end{array}$ & $\begin{array}{l}\text { Nilai dilewati moda } \\
\text { transportasi } 6 \leq \text { nilai }<9\end{array}$ \\
\hline \multirow{2}{*}{$\begin{array}{l}\text { Ketersediaan } \\
\text { Lahan Parkir } \\
\text { dalam } \\
\text { mendukung } \\
\text { pusat Aktivitas }\end{array}$} & \multirow[t]{2}{*}{$\begin{array}{l}\text { Kebutuhan } \\
\text { lahan parkir }\end{array}$} & \multirow{2}{*}{$\begin{array}{l}\text { Mengetahui ketersediaan } \\
\text { lahan parkir pada ke tiga } \\
\text { ruas jalan Kantor } \\
\text { Pemerintahan Terpadu } \\
\text { Kabupaten Boyolali dan di } \\
\text { dalam kantor pemerintahan } \\
\text { terpadu }\end{array}$} & $\begin{array}{l}\text { Siap mendukung pusat } \\
\text { aktivitas }\end{array}$ & $\begin{array}{l}\text { Nilai ketersediaan lahan } \\
\text { parkir } 48,5 \leq \text { nilai } \leq 72\end{array}$ \\
\hline & & & $\begin{array}{l}\text { Tidak siap mendukung } \\
\text { pusat aktivitas }\end{array}$ & $\begin{array}{l}\text { Nilai ketersediaan lahan } \\
\text { parkir } 25 \leq \text { nilai< } 48,5\end{array}$ \\
\hline \multirow[t]{2}{*}{$\begin{array}{l}\text { Fungsi Sarana } \\
\text { dan Prasarana } \\
\text { Jalan }\end{array}$} & \multirow{2}{*}{$\begin{array}{l}\text { Tersedia dan } \\
\text { berfungsinya } \\
\text { sarana dan } \\
\text { prasarana } \\
\text { jalan }\end{array}$} & \multirow[t]{2}{*}{$\begin{array}{l}\text { Mengetahui sarana dan } \\
\text { prasarana fungsi jalan }\end{array}$} & $\begin{array}{l}\text { Tersedia sarana dan } \\
\text { prasarana jalan yang siap } \\
\text { mendukung pusat aktivitas }\end{array}$ & $\begin{array}{l}\text { Nilai fungsi sarana dan } \\
\text { prasarana jalan } \\
27 \leq \text { nilai } \leq 36 \\
\end{array}$ \\
\hline & & & $\begin{array}{l}\text { Tidak tersedia sarana dan } \\
\text { prasarana jalan yang } \\
\text { memadai untuk mendukung } \\
\text { pusat aktivitas }\end{array}$ & $\begin{array}{l}\text { Nilai fungsi sarana dan } \\
\text { prasarana jalan } \\
18 \leq \text { nilai }<27\end{array}$ \\
\hline \multirow[t]{2}{*}{$\begin{array}{l}\text { Tingkat fungsi } \\
\text { lembaga untuk } \\
\text { mengatur } \\
\text { fungsi jalan }\end{array}$} & \multirow[t]{2}{*}{$\begin{array}{l}\text { Terdapat } \\
\text { Kelembagaan }\end{array}$} & \multirow[t]{2}{*}{$\begin{array}{l}\text { Mengetahui Lembaga yang } \\
\text { mengatur dalam sistem } \\
\text { kegiatan dan sistem } \\
\text { jaringan sehingga sistem } \\
\text { kegiatan dapat terakomodir } \\
\text { oleh sistem jaringan } \\
\text { dengan baik }\end{array}$} & $\begin{array}{l}\text { Terdapat lembaga yang } \\
\text { mengatur fungsi jalan } \\
\text { dengan penegakan kuat } \\
\text { (realisasi rencana dan } \\
\text { program terkait dengan } \\
\text { jalan) }\end{array}$ & $\begin{array}{l}\text { Nilai perhitungan variabel } \\
4,5 \leq \text { nilai } \leq 6\end{array}$ \\
\hline & & & $\begin{array}{l}\text { Terdapat lembaga yang } \\
\text { mengatur fungsi jalan } \\
\text { dengan penegakan lemah } \\
\text { (tidak adanya rencana dan } \\
\text { program terkait dengan } \\
\text { jalan setelah adanya kantor } \\
\text { pemerintahan terpadu) }\end{array}$ & $\begin{array}{l}\text { Nilai Perhitungan variabel } 3 \\
\leq \text { nilai }<4,5\end{array}$ \\
\hline
\end{tabular}

Sumber : Permatasari, Citra Ayu, dkk., 2017

Teknik analisis yang digunakan adalah teknik analisis skoring, dengan masing-masing variabel menghasilkan perhitungan tingkat kesiapan yang berbeda, tergantung pada data yang diperoleh dan perhitungan yang telah dilakukan. Hasil skoring tertinggi menandakan bahwa fungsi jalan telah siap melayani kegiatan kantor pemerintahan terpadu Kabupaten Boyolali, begitu pula sebaliknya apabila hasil skoring rendah menandakan bahwa fungsi jalan tidak siap mengakomodir kebutuhan pada pusat aktivitas Kantor Pemerintahan Terpadu Kabupaten Boyolali.

Masing-masing variabel memiliki skor maksimul adalah 2 dengan hasil penilaian "siap" dan skor minimum 1 dengan hasil penilaian "tidap siap". Jadi, pada hasil skoring ke tiga ruas jalan dikatakan siap apabila hasil skoring adalah 7 sampai dengan 12, dan jika fungsi jalan dikatakan tidak siap apabila hasil perhitungan skoring kurang dari sama dengan 6.

\section{HASIL DAN PEMBAHASAN}

Berdasar pada hasil analisis, maka dapat dijabarkan mengenai pembahasan terkait dengan analisis skoring pada masing-masing variabel. Berikut merupakan hasil penjabaran hasil analisis kesiapan fungsi jalan: 
(1) Ketuntasan dalam Pengembangan Jaringan Jalan

Dalam variabel ketuntasan dalam pengembangan jaringan jalan, menggunakan data bangkitan dan tarikan kawasan penelitian yang dihimpun melalui survey primer maupun survey sekunder diantaranya bangkitan dan tarikan 8 pintu masuk kantor pemerintahan terpadu dengan waktu pengambilan datahari senin dan jumat dengan lama waktu 1 jam yaitu pada jam 09.30 - 10.30 dan 13.30 -14.30 yang didasarkan pada jam operasional masyarakat melakukan kegiatan di Kantor Pemerintahan Terpadu Kabupaten Boyolali. Selain itu, menggunakan data jumlah tenaga kerja di masingmasing OPD yang berada di dalam kantor pemerintahan terpadu. Berdasarkan hasil penelitian, terdapat 4.602 bangkitan perjalan dalam tiap satuan jamnya. Berdasar pada DPU Pedoman Analisis Dampak Lalu Lintas Jalan Akibat Pengembangan Kawasan di Perkotaan, 2009 maka hasil penelitian variabel ketuntasan dalam pengembangan jaringan jalan dikatakan siap mendukung keberadaan kantor pemerintahan terpadu karena lebih dari 1.000 bangkitan perjalanan/jam dengan skor yang diperoleh adalah 2 .

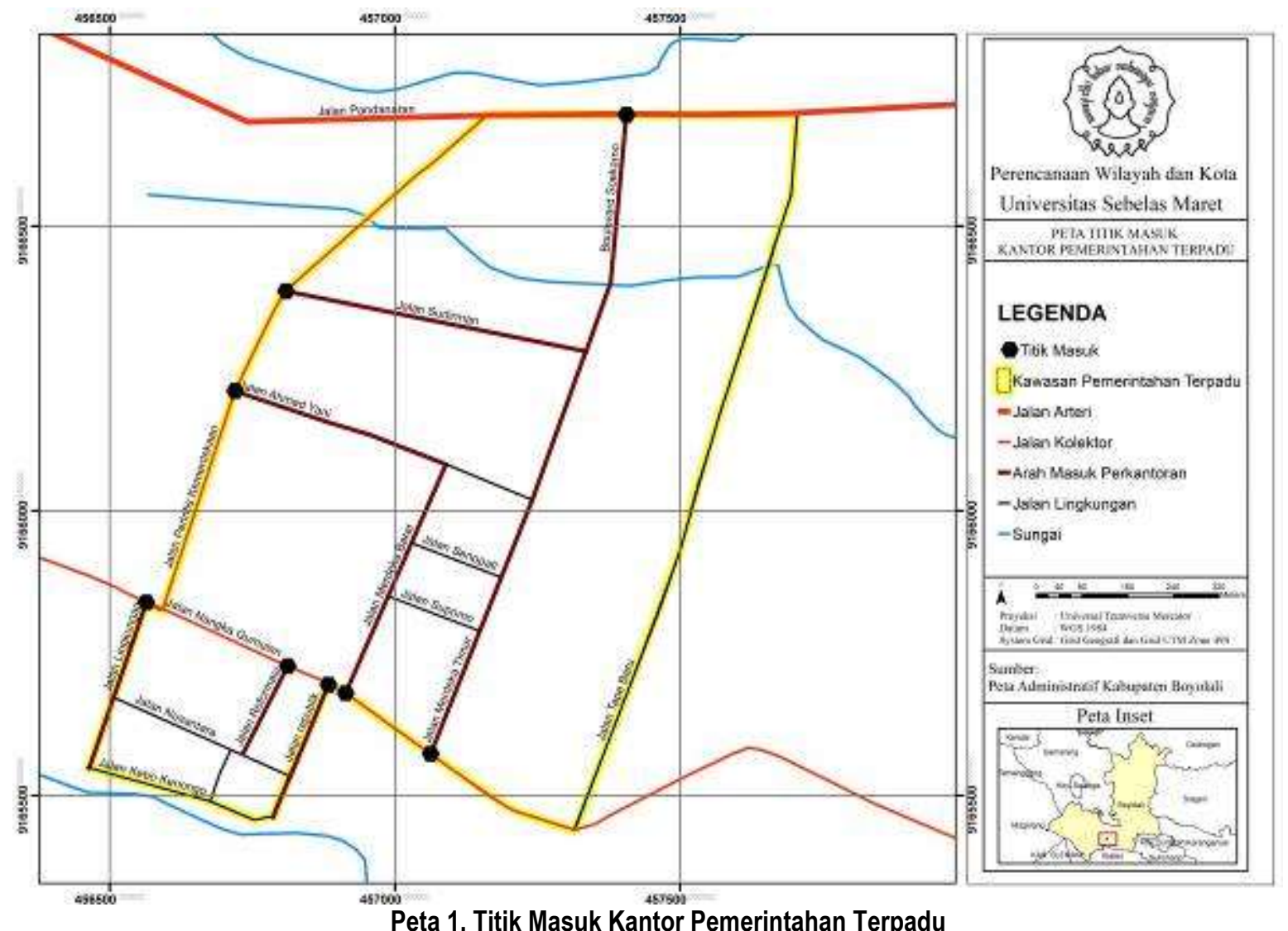

Dari hasil tersebut, keberadaan 8 pintu masuk sudah cukup efisien, sehingga mampu mengurangi kemacetan di pintu masuk utama yaitu boulvard Soekarno yang terletak di Jalan Pandanaran. Namun, lokasi pintu masuk yang berada di kantor pemerintahan terpadu bagian selatan, masih kurang terlihat sehingga masih perlunya penunjuk arah untuk 3 pintu masuk, diantaranya Jalan Reformasi, Jalan Republik dan Jalan Lingkungan

(2) Tingkat Pelayanan Jalan

Tingkat pelayanan jalan digunakan untuk mengetahui tingkat aksesibilitas kawasan. Perhitungan tersebut dapat diukur dari jumlah kendaraan bermotor yang melewati ketiga ruas jalan yaitu Jalan Pandanaran, Jalan Perintis Kemerdekaan dan Jalan Nangka Gumulan baik masuk maupun keluar melewati Kantor Pemerintahan Terpadu Kabupaten Boyolali. Data yang dihimpun berupa data sekunder yang diperoleh melalui survey instansi serta menggunakan data pada saat jam puncak yaitu pada pukul 06.30 sampai 07.30 , siang pukul 12.00 sampai 13.00 dan sore pukul 16.00 sampai 17.00 . 
Tabel 3. Tingkat Pelayanan Jalan

\begin{tabular}{|l|c|c|c|c|c|}
\hline \multicolumn{1}{|c|}{ Nama Jalan } & $\begin{array}{c}\text { Volume } \\
\text { Kendaraan(Q) }\end{array}$ & $\begin{array}{c}\text { Kapasitas } \\
\text { (smp/jam) }\end{array}$ & $\begin{array}{c}\text { Derajat Kejenuhan } \\
\text { (DS) }\end{array}$ & $\begin{array}{c}\text { Tingkat } \\
\text { Pelayanan }\end{array}$ & Nilai \\
\hline Jalan Pandanaran & 1274.85 & 4272.99 & 0.298 & $\mathrm{~B}$ & 5 \\
\hline Jalan Nangka Gumulan & 788.8 & 1779.21 & 0.443 & $\mathrm{~B}$ & 5 \\
\hline Jalan Perintis Kemerdekaan & 458.5 & 1799.67 & 0.254 & $\mathrm{~B}$ & 5 \\
\hline
\end{tabular}

Sumber : Permatasari, Citra Ayu, dkk., 2017

Berdasarkan hasil perhitungan tingkat pelayanan jalan pada tabel 3 menunjukkan bahwa tingkat pelayanan ke tiga ruas jalan tergolong dalam tingkat pelayanan B yaitu bagus. Volume kendaraan tertinggi berada pada ruas Jalan Pandanaran yang merupakan Jalan Nasional. Adapun hasil perhitungan variabel adalah 15 tergolong dalam tingkat pelayanan jalan tinggi dengan interval nilai $10,5 \leq$ nilai $\leq 18$.

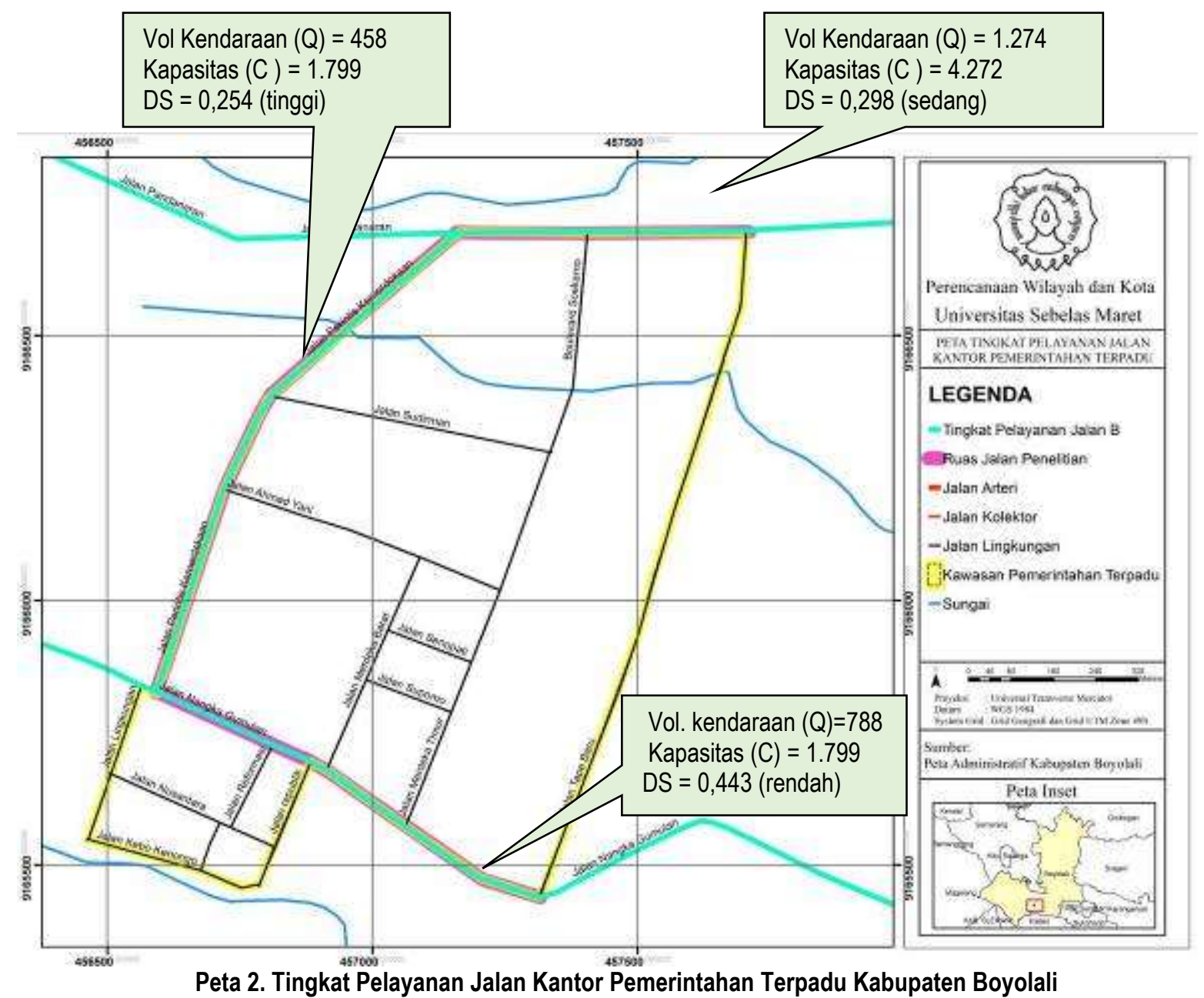

Dari hasil analisis yang telah dilakukan, maka perlunya peningkatan pelayanan jalan pada ke tiga ruas jalan agar tingkat pelayanan jalan menjadi ' $A$ " atau sangat baik, salah satunya dengan cara menyediakan lajur khusus untuk Jalan Perintis kemerdekaan, karena kondisi jalan yang satu arah untuk kendaraan berat namun dua arah untuk kendaraan ringan. Dari kondisi tersebut, bisa diberlakukan pemisah jalan untuk kendaraan ringan sehingga nantinya akan ada sparator atau pembatas jalan pada ruas Jalan Perintis Kemerdekaan. Selain itu, diperlukan rekayasa lalu lintas untuk mengurangi tumpukan arus lalu lintas di masing-masing ruas jalan salah satunya adalah perubahan rute jalan di Jalan Nangka Gumulan.

\section{(3) Ketersediaan Moda Transportasi}

Fungsi utama dari perhitungan variabel moda transportasi adalah untuk mengetahui apakah ke tiga ruas jalan penelitian, mampu dilewati moda transportasi yang dibutuhkan sesuai dengan aturan fungsi jalan yang telah ada. Berdasarkan hasil perhitungan diketahui bahwa ruas Jalan Pandanaran, Jalan Perintis Kemerdekaan dan Jalan Nangka 
Gumulan dilewati oleh moda transportasi roda dua berupa sepeda dan sepeda motor serta dilewati oleh moda transportasi roda empat sampai dengan kendaraan berat berupa bus dan truk.

Untuk Jalan Pandanaran merupakan jalan nasional yang menghubungkan Kota Surakarta dengan Kabupaten Semarang via Kabupaten Boyolali, sehingga semua kendaraan bisa melewati Jalan Pandaranan, yang kemudian untuk truk dan bus mengambil jalur lingkar selatan untuk menghindari perkotaan Boyolali. Sedangkan, Jalan Nangka Gumulan merupakan Jalan Provinsi yang menghubunugkan Kabupaten Boyolali dengan Kabupaten Klaten, sehingga semua kendaraan bisa melewati jalan tersebut, namun bus AKDP yang melewati Jalan Nangka Gumulan hanya bus AKDP Tulus Rapi, yang melayani kebutuhan masyarakat Kabupaten Boyolali bagian selatan.

Dari hasil perhitungan variabel ketersediaan moda transportasi dalam mendukung pusat kegiatan dapat disimpulkan bahwa variabel tersebut siap mendukung pusat kegiatan dengan hasil perhitungan adalah 12 yang masuk dalam interval perhitungan siap yaitu $9 \leq$ nilai $\leq 12$.

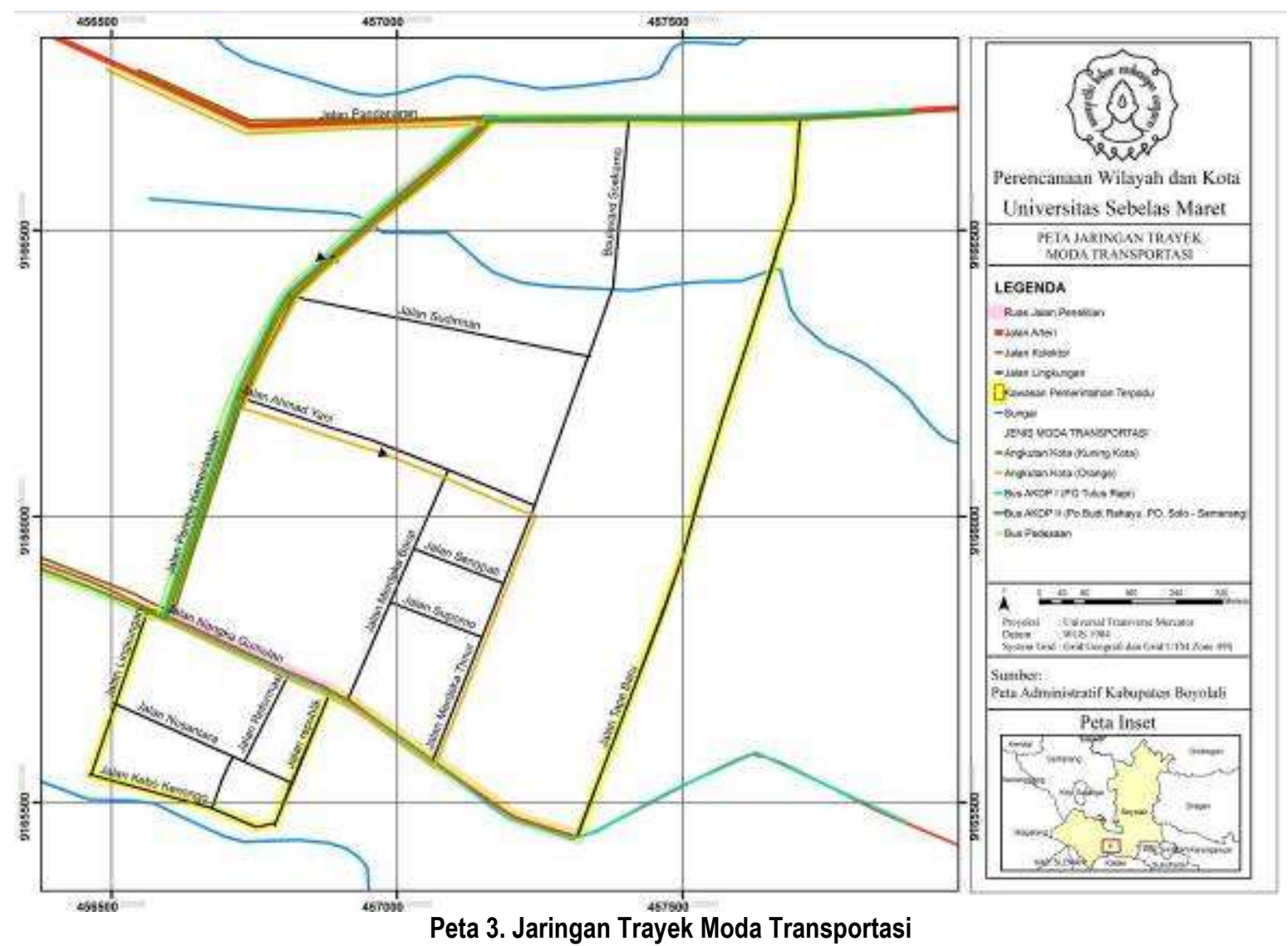

Ditemukan bahwa sudah tersedia moda transportasi berupa angutan orange nomor 01 yang masuk dalam Kantor Pemerintahan Terpadu Kabupaten Boyolali, namun ketersediaan angkutan tersebut belum tergolong banyak dan belum melewati seluruh jalan di dalam kantor pemerintahan terpadu, sehingga diperlukan adanya tambahan moda transportasi angkutan orange nomor 01 untuk mengakomodir seluruh kebutuhan di dalam Kantor Pemerintahan Terpadu Kabupaten Boyolali. Penambahan moda transportasi yang dimaksudkan agar bisa menjadi terobosan baru adalah ketersediaan moda angkutan dengan menggunakan bus khusus kantor pemerintahan terpadu seperti layaknya bus kampus. Bus khusus kantor pemerintahan terpadu tersebut hanya beroperasi di dalam kantor pemerintahan terpadu agar nantinya pengguna lebih merasa aman dan nyaman. Hal ini merupakan salah satu ide gagasan untuk memodifikasi operasi angkutan umum khususnya di dalam Kantor Pemerintahan Terpadu Kabupaten Boyolali. Hal utama yang perlu dilakukan adalah, kerjasama dengan Dinas Perhubungan untuk ijin trayek dan Dinas Bina Marga untuk ijin operasional moda transportasi.

(4) Ketersediaan Lahan Parkir dalam Mendukung Pusat Aktivitas

Dalam penelitian, pengkajian tentang ketersediaan lahan parkir dibagi menjadi dua yaitu lahan parkir di dalam Kantor Pemerintahan Terpadu Kabupaten Boyolali dan lahan parkir di bahu jalan. Jenis jalan pada ruas jalan penelitian yaitu 
arteri dan kolektor. Jalan arteri diantaranya Jalan Pandanaran dan jalan kolektor adalah Jalan Perintis Kemerdekaan dan Jalan Nangka Gumulan.

Berdasarkan data UPT Perparkiran, Dinas Perhubungan Kabupaten Boyolali bahwa di kawasan penelitian, tidak ditemukan ijin penggunaan lahan parkir bahu jalan baik untuk kawasan perdagangan jasa maupun lainnya. Namun, saat dilakukan observasi di tiga ruas jalan, ditemukan adanya parkir di bahu jalan, yaitu di ruas jalan Pandanaran.

Selain melihat ketersediaan lahan parkir di ke tiga ruas jalan, juga melihat ketersediaan lahan parkir di dalam Kantor Pemerintahan Terpadu Kabupaten Boyolali. Mengacu kebutuhan ruang parkir yang bersifat tetap untuk pusat perkantoran (Direkotar Jenderal Perhubungan Darat, 1998) dapat dianalisa bahwa jumlah seluruh pegawai kantor pemerintahan terpadu adalah 1.111 jiwa. Apabila dihitung menggunakan kebutuhan ruang parkir menurut Direktorat Jenderal Perhubungan Darat, maka kantor pemerintahan terpadu tersebut harus menyediakan lahan parkir seluas 523 $\mathrm{m}^{2}$, yang terbagi untuk kebutuhan administrasi (parkir karyawan) sebesar $235 \mathrm{~m}^{2}$ dan kebutuhan parkir pengunjung (pelayanan umum) sebesar $288 \mathrm{~m}^{2}$. Namun, dalam observasi tidak ditemukan adanya parkir komunal atau parkir khusus yang digabungkan menjadi satu. Seluruh kantor pemerintahan telah mempunyai parkir masing-masing, sehingga apabila diproporsi secara merata, masing-masing kantor pemerintahan minimal mempunyai lahan parkir seluas $23,7 \mathrm{~m}^{2}$ baik untuk karyawan maupun pengunjung. Berikut merupakan kondisi ketersediaan lahan parkir di masing-masing kantor di dalam Kantor Pemerintahan Terpadu Kabupaten Boyolali.
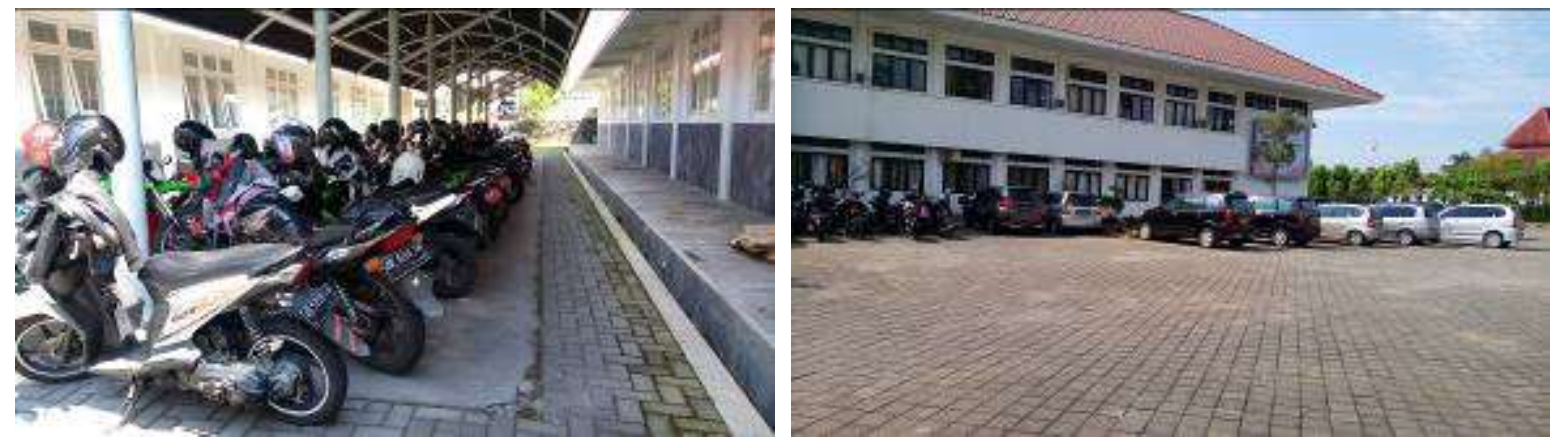

Sumber : Permatasari, Citra Ayu, dkk., 2017

Gambar 2 Ketersediaan Lahan Parkir Kantor Dinas di Kantor Pemerintahan Terpadu Kabupaten Boyolali

Berdasarkan pembobotan ketersediaan lahan parkir dalam mendukung pusat aktivitas yang diperoleh dari perhitungan ketersediaan lahan parkir di bahu jalan dan di dalam kantor pemerintahan terpadu adalah 71 , sehingga masuk dalam interval nilai $48,5 \leq$ nilai $\leq 72$. Oleh karena itu, variabel ketersediaan lahan parkir dalam mendukung pusat aktivitas dapat dikatakan siap mendukung pusat kegiatan.

Namun, dalam proses perhitungan variabel, ditemukan parkir liar di ruas Jalan Pandanaran. Hal ini tentunya, merupakan hal yang perlu diselesaikan oleh Dinas Perhubungan, khususnya UPT Perparkiran untuk lebih mensosialisasikan larangan parkir di badan jalan khususnya pada fungsi jalan arteri karena bisa mengganggu kegiatan lalu lintas. Sosialisasi larangan parkir bisa dilakukan dengan himbauan atau penerapan rambu larangan parkir pada ruas-ruas jalan tertentu. Untuk mendukung adanya terobosan baru yaitu moda transportasi khusus kantor pemerintahan terpadu, maka diperlukan adanya parkir komunal agar nantinya seluruh kegiatan di dalam kantor pemerintahan terpadu bisa ramah lingkungkan. Salah satunya dengan adanya parkir komunal maka keberadaan bus kantor akan bisa optimal. Hal ini juga didukung dengan adanya sarana pejalan kaki di dalam kantor pemerintahan terpadu, yang bisa mendukung keberadaan kantor pemerintahan terpadu dengan tema Kantor Pemerintahan Terpadu yang Ramah Lingkungan. 


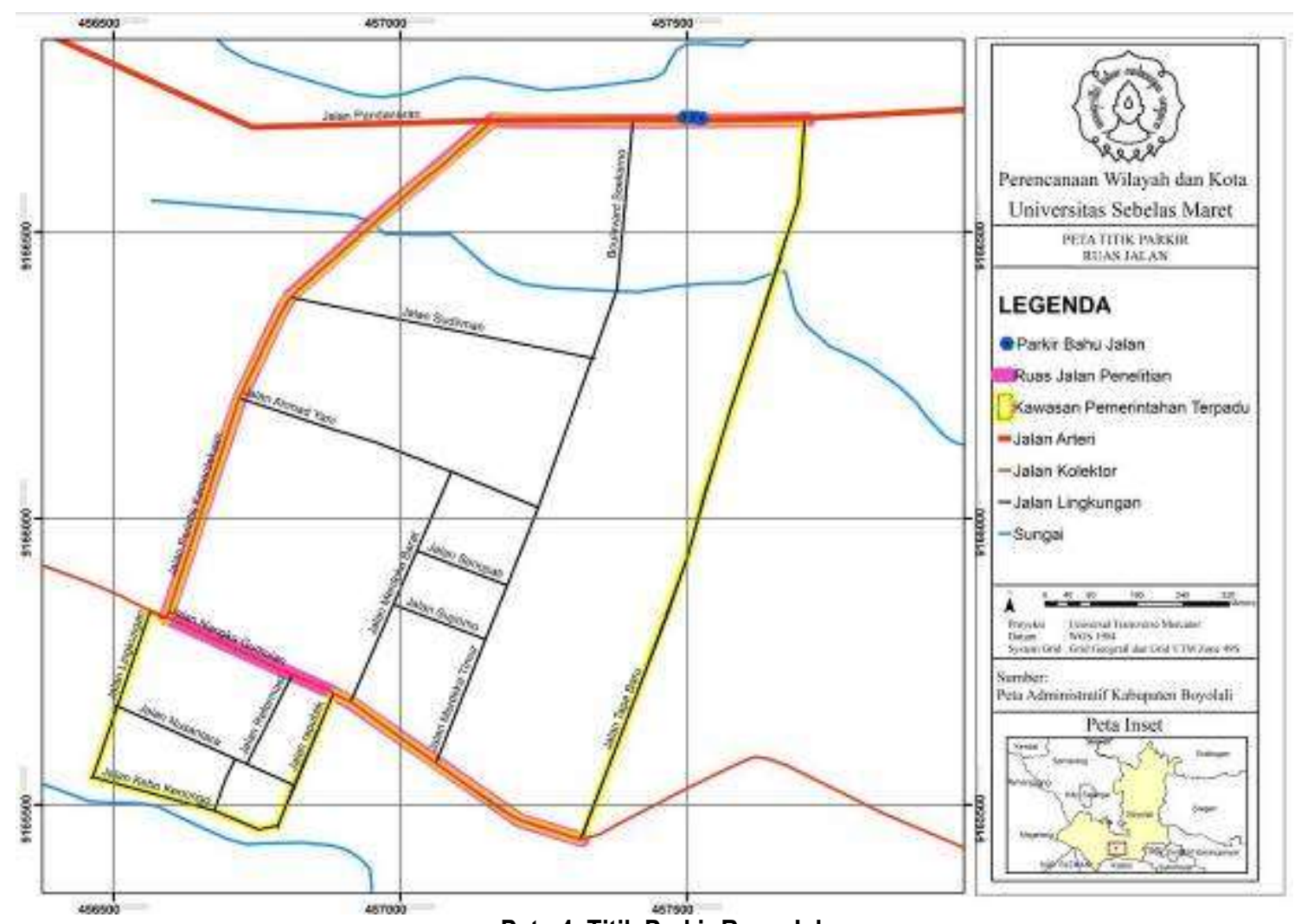

Peta 4. Titik Parkir Ruas Jalan

(5) Fungsi Sarana dan Prasarana Jalan

Data terkait sarana dan prasarana jalan, diperoleh melalui survey sekunder yaitu ke Dinas Perhubungan dan observasi secara langsung pada tiga ruas jalan penelitian. Penilaian variabel sarana dan prasarana jalan dilakukan berdasarakan ruas jalan. Menurut Miro, (2012) adapun kriteria yang digunakan dalam perhitungan variabel diantaranya, ketersediaan parkir di dalam kawasan/ruas jalan (untuk fungsi jalan arteri, tidak diijinkan adanya parkir di bahu jalan), tersedia dan berfungsi nya rambu penunjuk jalan, tersedia dan berfungsinya marka jalan, tersedia dan berfungsinya lajur khusus kendaraan berat, tersedia dan berfungsinya halte/tempat pemberhentian umum, tersedia dan berfungsinya batas kecepatan fungsi jalan.

Hasil analisis variabel fungsi sarana dan prasarana jalan menjelaskan bahwa skor total perhitungan adalah 26, yang masuk dalam interval 6,1-21 yaitu dalam parameter tidak siap. Oleh karena itu, dapat disimpulkan bahwa variabel fungsi sarana dan prasarana jalan tidak siap mendukung pusat aktivitas Kantor Pemerintahan Terpadu Kabupaten Boyolali.

Melihat variabel fungsi sarana dan prasarana jalan, apabila diterapkan pada ruas Jalan Pandanaran, dengan fungsi jalan arteri yang mempunyai kecepatan tinggi maka diperlukan adanya lajur khusus kendaraan berat atau bisa disebut dengan pembatas jalan/sparator. Hal ini difungsikan untuk meminimalisir angka kecelakaan akibat tingginya kecepatan pada fungsi jalan arteri. Selain itu, pada ruas Jalan Pandanaran, selain memiliki fungsi arteri, juga memiliki fungsi lokal karena manjadi pintu masuk utama menuju Kantor Pemerintahan Terpadu Kabupaten Boyolali, sehingga pembatasan jalan tersebut diperlukan pada ruas Jalan Pandanaran. Selain itu, sarana dan prasarana yang dibutuhkan di antaranya penambahan lajur khusus bus untuk Jalan Perintis Kemerdekaan, sarana fasilitas pejalan kaki untuk ruas Jalan Perintis Kemerdekaan, rambu untuk jalur satu arah atau with flow bus lane, rambu "STOP" dan "YIELD" untuk simpang tak bersinyal di Jalan Nangka Gumulan. 


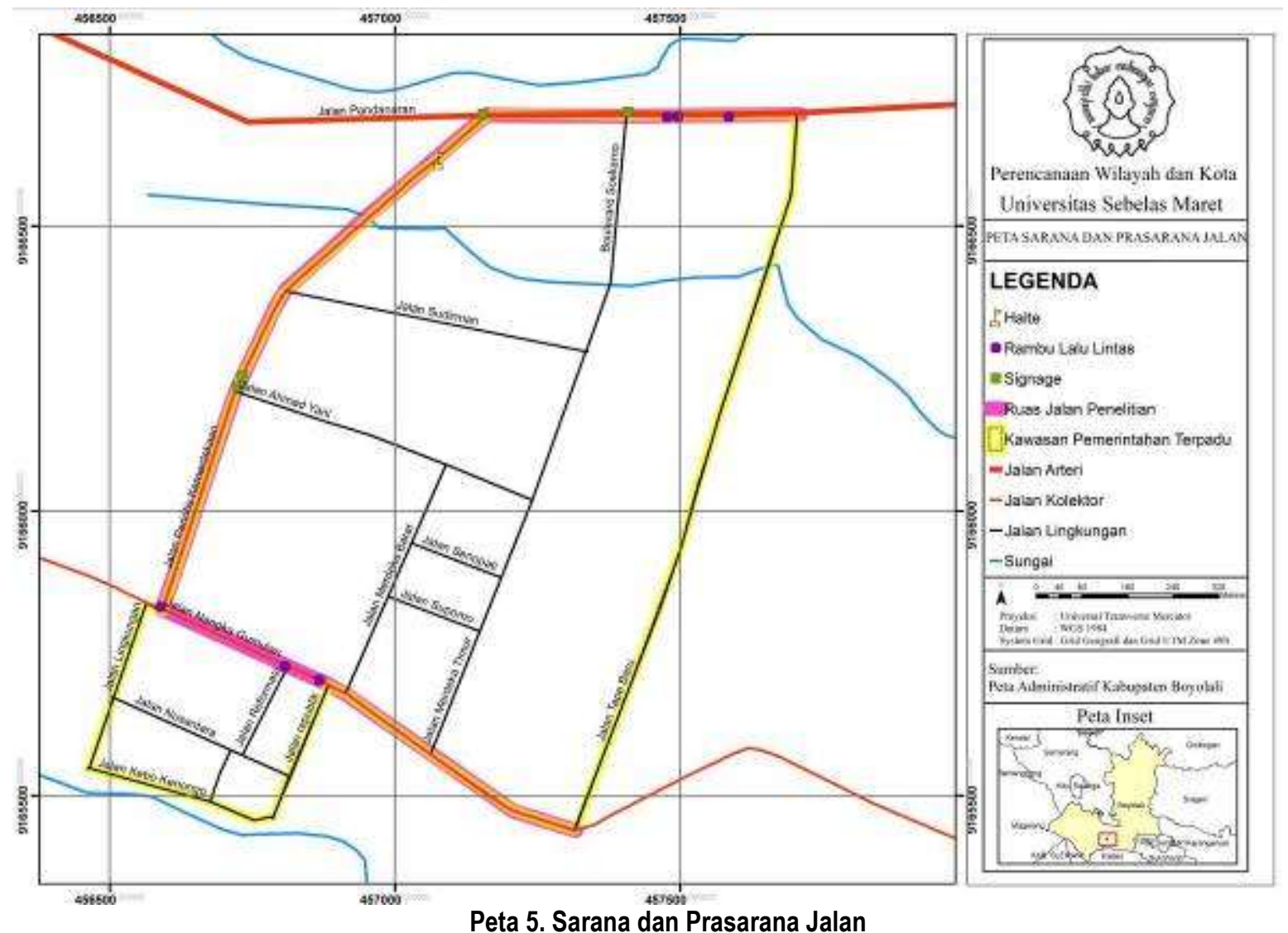

(6) Tingkat Fungsi Lembaga untuk Mengatur Fungsi Jalan

Lembaga yang mengatur fungsi jalan dalam penelitian ini adalah pemerintah provinsi dan nasional. Melihat fungsi dari masing-masing jalan beserta wewenangnya antara lain, Jalan Perintis Kemerdekaan dan Jalan Pandanaran merupakan Jalan Nasional dengan di bawah tanggung jawab pemerintah pusat sedangkan Jalan Nangka Gumulan merupakan jalan provinsi di bawah tanggung jawab Pemerintah Provinsi Jawa Tengah yaitu Bina Marga Jawa Tengah. Berdasarkan data yang telah dihimpun dari Dinas Bina Marga (Perencanaan dan Pengawasan Jalan Nasional) untuk Jalan Pandanaran dan Perintis Kemerdekaan dengan batasan wilayah yang telah dijelaskan sebelumnya, bahwa ke dua ruas jalan tersebut tidak memiliki rencana pengembangan jaringan jalan dalam menanggapi adanya pembangunan Kantor Pemerintahan Terpadu Kabupaten Boyolali.

Jalan Nangka Gumulan, merupakan Jalan Provinsi di bawah naungan Dinas Bina Marga Jawa Tengah. Jalan tersebut merupakan penghubung antara Kabupaten Boyolali dengan Kabupaten Klaten. Sama halnya dengan dua ruas jalan lainnya, Jalan Nangka Gumulan dalam batas wilayah penelitian tidak memiliki rencana pengembangan jaringan jalan dalam menanggapi adanya pembangunan Kantor Pemerintahan Terpadu Kabupaten Boyolali. Berdasarkan hasil analisis, dapat disimpulkan bahwa variabel tingkat fungsi lembaga untuk mengatur fungsi jalan dengan hasil 3 . Skor 3 dikatakan masuk dalam interval $3 \leq$ nilai $<4,5$ yang tergolong tidak siap mendukung pusat aktivitas.

Melihat realita di lapangan, bahwa ruas Jalan Tape Baru memiliki kondisi jalan yang buruk karena tidak terawat namun sampai saat ini jalan tersebut digunakan sebagai jalan alternatif menuju Jalan Pandanaran. Oleh karenanya, diperlukan adanya rencana rekayasa lalu lintas untuk mengembangkan jalan tersebut. Rekayasa lalu lintas yang bisa dijadikan terobosan baru, di ataranya, menjadikan Jalan Nangka Gumulan satu arah (barat ke timur) pada jam-jam tertentu seperti pagi dan sore hari saat peak hours. Apabila akan melakukan pergerakan menuju perkotaan Boyolali bisa melewati Jalan Pandanaran via jalur alternatif yaitu Jalan Tape Baru (selatan ke utara). Untuk mendukung adanya rekayasa lalu lintas, tentunya membutuhkan stakeholder terkait seperti Dinas Perhubungan dan Dinas Bina Marga. Sebab perubahan arus yang terjadi akan menyebabkan dampak baik positif dan negatif yang harus dikaji terlebih dahulu. Selain itu, adanya perubahan rute jalan juga membutuhkan sosialisasi berupa rambu-rambu lalu lintas sehingga akan lebih memudahkan masyarakat dalam menerima informasi. 
Dari hasil skoring tiap variabel, kemudian dilakukan sintesis hasil skoring yang merupakan hasil akhir dari seluruh penilaian variabel. Sintesis hasil skoring mempunyai kesimpulan apakah fungsi jalan pada ketiga ruas jalan yaitu Jalan Perintis Kemerdekaan, Jalan Pandanaran dan Jalan Nangka Gumulan siap mendukung Kantor Pemerintahan Terpadu Kabupaten Boyolali atau tidak. Berikut merupakan tabel sintesis skoring variabel:

Tabel 4. Sintesis Hasil Skoring Variabel

\begin{tabular}{|c|c|c|}
\hline \multirow{2}{*}{ VARIABEL } & \multicolumn{2}{|c|}{ KESIAPAN } \\
\hline & 2 (SIAP) & 1 (TIDAK SIAP) \\
\hline $\begin{array}{l}\text { Ketuntasan dalam } \\
\text { pengembangan } \\
\text { jaringan jalan }\end{array}$ & $\begin{array}{l}\text { Hasil skoring variabel ketuntasan dalam rencana } \\
\text { pengembangan pusat kegiatan adalah } 2\end{array}$ & - \\
\hline Tingkat pelayanan jalan & $\begin{array}{l}\text { Tingkat pelayanan jalan tinggi dengan hasil } \\
\text { perhitungan } 15 \text { dari interval nilai } 10,5 \leq \text { nilai } \leq 18\end{array}$ & - \\
\hline $\begin{array}{l}\text { Ketersediaan moda } \\
\text { transportasi }\end{array}$ & $\begin{array}{c}\text { Jalan dilewati oleh moda transportasi tertentu } \\
\text { dengan hasil perhitungan } 12 \text { dari interval nilai } 9 \\
\leq \leq \text { nilai } \leq 12\end{array}$ & - \\
\hline $\begin{array}{l}\text { Ketersediaan lahan } \\
\text { parkir dalam } \\
\text { mendukung pusat } \\
\text { aktivitas } \\
\end{array}$ & $\begin{array}{c}\text { Tersedia lahan parkir di dalam kawasan dengan } \\
\text { hasil perhitungan nilai ketersediaan } 71 \text { dari } \\
\text { interval nilai } 48,5 \leq \text { nilai } \leq 72\end{array}$ & \\
\hline $\begin{array}{l}\text { Fungsi sarana dan } \\
\text { prasarana jalan }\end{array}$ & - & $\begin{array}{c}\text { Nilai ketersediaan sarana dan } \\
\text { prasarana } 26 \text { dari interval nilai } 18 \leq \\
\text { nilai }<27\end{array}$ \\
\hline $\begin{array}{l}\text { Tingkat fungsi lembaga } \\
\text { untuk mengatur fungsi } \\
\text { jalan }\end{array}$ & - & $\begin{array}{c}\text { Jika hasil skoring variabel tingkat } \\
\text { fungsi lembaga adalah } 3 \text { dari interval } \\
\text { nilai } 3 \leq \text { nilai }<4,5\end{array}$ \\
\hline
\end{tabular}

Sumber : Permatasari, Citra Ayu, dkk., 2017

Berdasarkan hasil sintesis skoring bahwa fungsi Jalan Perintis Kemerdekaan, Jalan Pandanaran dan Jalan Nangka Gumulan dalam mengakomodir adanya pembangunan Kantor Pemerintahan Terpadu Kabupaten Boyolali, dapat dikatakan "siap" mendukung Kantor Pemerintahan Terpadu Kabupaten Boyolali karena dari hasil penelitian ke tiga ruas jalan mampu berfungsi dengan optimal dengan hasil skoring 10 yang masuk dalam interval skor siap adalah 7 sampai dengan 12.

\section{KESIMPULAN}

Berdasarkan hasil penelitian yang telah dilakukan oleh penulis, maka diperoleh hasil tingkat kesiapan pada ke tiga ruas jalan adalah siap mendukung Kantor Pemerintahan Terpadu Kabupaten Boyolali. Dikatakan siap karena, berdasarkan hasil perhitungan yang telah dilakukan dengan menggunakan 6 variabel penelitian, diperoleh hasil bahwa 4 dari 6 variabel menghasilkan perhitungan "siap" dengan hasil skoring adalah 10, sedangkan 2 variabel lainnya menghasilkan perhitungan "tidak siap".

Tingkat kesiapan fungsi jalan dilakukan dengan beberapa variabel, dalam variabel-variabel tersebut diperlukan adanya rekayasa lalu lintas terkait dengan recana pengembangan jaringan jalan untuk mendukung fungsi jalan di ruas jalan Kantor Pemerintahan Terpadu Kabupaten Boyolali. Rekayasa lalu lintas yang diangkat dalam penelitian adalah pengembangan potensi Jalan Tape Baru guna mengurangi kepadatan lalu lintas di ruas Jalan Nangka Gumulan.

\section{DAFTAR PUSTAKA}

Business Dictionary website http://www.businessdictionary.com/definition/readiness.html

Direktorat Jenderal Perhubungan Darat. (1998). Pedoman Perencanaan dan Pengoperasian Fasilitas Parkir. Jakarta.

Departemen Pekerjaan Umum. (2009). Pedoman Analisis Dampak Lalu Lintas Jalan Akibat Pengembangan Kawasan di Perkotaan. Miro, Fidel. (2012). Pengantar Sistem Transportasi. Jakarta: Penebit Erlangga

Mujihartono, Eko. (1996). Studi Sistem Jaringan Jalan Kota Semarang. Semarang: Universitas Diponegoro

Munawar. Ahmad. (2004). Manajemen Lalu Lintas Perkotaan. Jogjakarta: Beta Offset

Nelson, Willis, et al. (2009). Initial Evaluation of the Cities Readiness Initiative. RAND Corporation 
Desa-Kota, Vol. 1, No. 2, 2019, 153-166

Rencana Tata Ruang Wilayah Kabupaten Boyolali Tahun 2011-2031

Tamin, Ofyar. Z. (1997). Perencanaan dan Pemodelan Transportasi. Bandung: ITB

Undang-Undang Republik Indonesia Nomor 38 Tahun 2004 tentang Jalan

Yunus, H. S, (1999). Struktur Tata Ruang Kota. Yogyakarta: Pustaka Pelajar 